\title{
Unsuitable Cases: The Debate over Outpatient Admissions, the Medical Profession and late-Victorian London Hospitals
}

\author{
KEIR WADDINGTON*
}

In 1836 a meeting of the nascent British Medical Association (BMA) expressed concern over the "vast amount of gratuitous medical assistance" offered by London's voluntary hospitals. ${ }^{1}$ Seventeen years later, the British Medical Journal printed Edward Crossman's presidential address to the Bath and Bristol branch of the BMA, which highlighted the issue as one of professional concern. ${ }^{2}$ In the intervening years there was little comment on the subject, but Crossman's address marked the start of a protracted and circular debate. Initially, few medical journals took up Crossman's lead. In 1856 the Medical Times and Gazette noted in passing that the resident medical officer of St Thomas's Hospital had written to The Times to complain about the odious position of the capital's outpatient departments. He declared that donations and subscriptions were being misapplied and used to fund the treatment of patients who could afford to pay for their medical care. ${ }^{3}$ No systematic solution other than a restriction of governors' admission privileges, or "letters", was proposed and the Gazette took the issue no further. ${ }^{4}$ Within ten years the idea that metropolitan outpatient departments were being abused by undeserving and, above all, middle-class patients had become a matter of widespread anxiety within London's medical profession. Similar concerns had been expressed in the 1840 s and 1850 s over friendly society medical schemes and sick clubs. ${ }^{5}$ By 1889 the debate had reached such an intensity that the British Medical Journal felt it necessary to inform its readers that moderation should be exercised in a discussion that had become

* Keir Waddington, PhD, Wellcome Institute for the History of Medicine, 183 Euston Road, London NW1 2BE.

\footnotetext{
${ }^{1}$ Cited in Edward Crossman's Address, Br. med. J., 1883 , ii: $61-7,64$.

2 'House of hospitals and dispensaries: a monster evil of the day', Association Medical Journal, 1853, i: $76-7$.

${ }^{3}$ Med. Times Gaz., 1856, p. 33. Patients were not means-tested and no equivalent of the modern social worker was present until the 1880 s.

${ }^{4}$ Procedures varied between hospitals, but the aim remained the same and governors' "letters" became the "traditional way of enticing members of
}

the public to subscribe" (B Abel-Smith, The hospitals, 1800-1948, London, Heinemann, 1964, p. 36). Essentially it was a scheme of incentives. Letters were given to those who contributed to the hospital on a graduated scale linked to the size of contribution. Each letter carried the right to admit a patient. In theory they guaranteed treatment or at least the attention of a doctor, and in the outpatient departments such letters ensured that the holder was examined first.

${ }^{5}$ See D Green, Working-class patients and the medical establishment: self-help in Britain from the mid-nineteenth century to 1948, London, Gower, 1985, pp. 14-16. 


\section{The Debate over Outpatient Admissions to London Hospitals}

"the burning question of the hospital world". 6 Provincial doctors and medical societies were slow to pick up the issue, but in 1905 Samuel Squire Sprigge, future editor of the Lancet, felt that the problem was one of national and international importance. ${ }^{7}$ Where the issue became integral to debates on British hospital medicine in the late-nineteenth century, it centred on the London hospitals, already plagued by what appeared to be an endemic financial crisis. Articles were written, conferences were held, and voluntary associations were established to promote reform, but the problem remained unresolved.

Discussion lingered on into the twentieth century. In 1910 the King Edward's Hospital Fund for London organized a committee chaired by Lord Mersey to investigate abuse. ${ }^{8}$ After hearing evidence from forty-eight witnesses, the committee found that there was no sharp financial distinction between deserving patients, those who were traditionally considered suitable objects for charity, given their poor but industrious nature, and the slightly better-off. It conceded that there was some overlap between outpatient departments and other forms of treatment. ${ }^{9}$ The Fund's authoritative statement did little to pacify critics of the outpatients' system, who continued to clamour for reform. However, their arguments were increasingly anachronistic in a society that was being gradually weaned from the gospel of independence and self-help onto a reluctant acceptance of state intervention. ${ }^{10}$

The setting up of the Fund's committee was a recognition that, despite impassioned debate, no real progress had been made since the 1850s. Reformers remained divided; hospital governors were unwilling to promote extensive change for fear of sabotaging their position in the highly competitive environment of metropolitan philanthropy. Vacillation concealed very real concerns about issues that extended beyond the London hospitals. Brian Abel-Smith has argued that the debate symbolized a bitter dispute within the medical profession between general practitioners and hospital consultants, and reflected general practitioners' anxiety that consultants were stealing patients and

\footnotetext{
6 'Abuse of hospitals', Br. med. J., 1889, ii: 202; Editorial, Hospital, 18 Jan. 1890, p. 243.

${ }^{7}$ S Squire Sprigge, Medicine and the public, London, Heinemann, 1905, pp. 57-67.

${ }^{8}$ For a history of the King's Fund and its influence on the London hospitals see F K Prochaska, Philanthropy and the hospitals of London: The King's Fund 1897-1990, Oxford, Clarendon Press, 1992.

${ }^{9}$ King's Fund, Enquiry into the management of outpatient departments, London, s.n., 1912.

${ }^{10} \mathrm{By}$ the end of the nineteenth century the role of the state in welfare provision was being discussed in some quarters in less antagonistic terms. Collectivists and progressive idealists even made a virtue of state action. See S Collini, Public moralists: political thought and intellectual life in Britain 1850-1930, Oxford, Clarendon Press, 1991; J Harris, 'Political thought and the welfare state 1870-1940: an intellectual framework for British social policy', Past
}

and Present, 1992, No. 134-5: 116-41; and G Finlayson, 'A moving frontier: voluntarism and the state in British social welfare 1911-1949', TwentiethCentury Br. Hist., 1990, 1: 183-206. Hostility to state intervention still existed as voluntarism remained the dominant and desired mode of relief, but, by the twentieth century, there began to be doubts about voluntarism's ability to cope with urban poverty. In terms of medical relief, reformers like Henry Burdett and Robert Reid Rentoul were beginning to see the need for government support to solve the hospitals' pressing financial problems, but they remained on the margins of the debate until after the First World War, when the ability of voluntarism to solve an apparent endemic financial crisis seemed more uncertain. See H C Burdett, Hospitals and the state, London, Churchill, 1881, and Robert R Rentoul, The reform of our voluntary medical charities, London, Baillière, Tindall and Cox, 1891. 


\section{Keir Waddington}

damaging practices. ${ }^{11}$ Irvine Loudon has noted similar concerns. ${ }^{12}$ Letters from general practitioners to the medical press figured prominently, but the debate was more than a rank-and-file attack. For general practitioners and hospital doctors, who dominated the discussion, outpatient abuse was an important professional issue. They bemoaned the damaging effect such departments had on private practice and the conditions under which those working in hospitals laboured. The metropolitan hospitals stood at the heart of the debate because in London the problems appeared more pressing. Under cover of a discourse that emphasized the age-old problem of limiting charitable relief to the deserving poor and played upon wider concerns about the utility and means of giving, doctors attempted to exert control over the hospital and match its practices to their expectations. Philanthropists were less Machiavellian in their concern and the issue became part of a wider discussion of charity reform. Led by the Charity Organisation Society (COS), philanthropists voiced concerns that free medical care encouraged pauperism and that hospitals wasted charitable resources by treating a mixture of patients who could afford to pay for their care, and those whose level of poverty meant they were more suited to Poor Law relief. ${ }^{13}$ The distinction between the deserving and undeserving poor was often ill-defined, but in the debate "undeserving" increasingly came to symbolize those who could afford to pay for their treatment. Studies conflicted, but the general opinion was that the capital's outpatient departments were in urgent need of change.

Outpatient abuse was an important issue for philanthropists, hospital reformers, consultants and general practitioners. It reflected their different views of the hospital and its function, and, in the process, aroused public concern. Many solutions were suggested, from the closure of outpatient departments to an encouragement of provident habits through the dispensary movement, but only the COS's brand of inquiry and almoner scheme were effectively implemented. ${ }^{14}$ Inquiry into the personal circumstances of outpatients presented a non-radical solution that both conservative hospital governors and doctors found acceptable. This article seeks to understand the extent of abuse and look at the issues behind the debate. It contends that there was no sudden influx of undeserving

\footnotetext{
${ }^{11}$ Abel-Smith, op. cit., note 4 above, pp. 101-18. The professionalization of medicine has sparked a prolonged controversy. For T Gelfand, 'Decline of the ordinary practitioner and the rise of the modern medical profession', in S Staum and D E Larson, Doctors, patients and society: power and authority in medical care, Ontario, Wilfrid Laurier University, 1981, and I Waddington, Medical profession in the industrial revolution, Dublin, Gill \& Macmillan, 1984, professionalization was located in the change from a client-dominated practice in the eighteenth century to a doctor-dominated practice in the nineteenth. M J Peterson, The medical profession in mid-Victorian London, Berkeley, University of California Press, 1978, sets the vital period between 1858 and 1886. A more recent view is that of Loudon who argues that by 1850 "the main structure of the present medical profession had been created": I Loudon, Medical care and the general practitioner,
}

1750-1850, Oxford, Clarendon Press, 1987, p. 3. The period of professionalization might be in some doubt, but it seems reasonable to argue that during the second half of the nineteenth century a bicameral medical profession had begun to emerge.

12 I S L Loudon, 'Historical importance of outpatients', Br. med. J., 1978, i: 974-7.

${ }^{13}$ For the history of the COS see C Mowat, The Charity Organization Society 1869-1913, London, Methuen, 1961; M Rooff, A hundred years of family welfare, London, Joseph, 1972, and R Humphreys, 'Poor law and charity: the Charity Organisation Society in the provinces $1870-1890$ ', $\mathrm{PhD}$ thesis, University of London, 1991, for a more critical interpretation.

${ }^{14}$ For an overview of dispensaries see I S L Loudon, 'Origins and growth of the dispensary movement in England', Bull. Hist. Med., 1981, 55 : $322-42$. 


\section{The Debate over Outpatient Admissions to London Hospitals}

patients as contemporaries feared and that the belief was generated largely by hospital medical staff in an attempt to control their working practices.

\section{A Misapplication of Charity}

The medical market in nineteenth-century London was complex and stratified. The voluntary general, specialist and teaching hospitals, with their traditions of treating acute cases, were not the main providers of health care. In $1896,58,550$ sick poor were treated under the Poor Law, 22,100 in separate infirmaries, where care focused on the chronic sick that other institutions discouraged. ${ }^{15}$ The myriad of provident and free dispensaries, friendly societies, and clubs treated many more patients, numbers that are not amenable to quantitative analysis. Workhouse infirmaries existed side-by-side with hospitals, and between them were the numerous private practices from the fashionable Harley Street to the warrens of St Giles. Hospitals, however, experienced the fastest growth and a disproportionate amount of contemporary and professional attention. From the 1850s onwards, London's hospitals underwent a dramatic increase in admissions. Services expanded to meet demand, inspiring a building mania that left many institutions facing severe financial difficulties. ${ }^{16}$ From 1873 to 1893 inpatient admissions in London rose from 39,931 to 68,319 , though the metropolitan population had grown by only 27.6 per cent. By 1907 Burdett's Hospitals and charities estimated that half the population of London obtained free medical relief, although the figure was not typical of the country as a whole. Individual hospitals experienced a more substantial rise than these figures suggest. Outpatient departments expanded at a faster rate than hospital wards. Outpatient services had emerged in the eighteenth century, but expansion did not really begin until

Table 1

Patient Admissions to the Principal General Hospitals in London

\begin{tabular}{lrrrr}
\hline Hospital & \multicolumn{2}{c}{ Inpatients } & \multicolumn{2}{c}{ Outpatients } \\
& 1809 & 1895 & 1809 & 1895 \\
\hline St Bartholomew's & 3,849 & 6,674 & 45,401 & 59,063 \\
St Thomas's & 2,789 & 6,150 & 4,322 & 112,056 \\
Westminster & 627 & 2,934 & 687 & 24,247 \\
St George's & 1,450 & 4,191 & 1,211 & 28,392 \\
The London & 1,406 & 10,599 & 877 & 152,411 \\
Middlesex & 555 & 3,404 & 522 & 41,706 \\
\hline
\end{tabular}

Source: G Rivett, Development of the London hospital system 1823-1982, London, Oxford University Press, 1986, p. 140.

\footnotetext{
${ }^{15}$ F Cartwright, $A$ social history of medicine, London, Longman, 1977, p. 159.

16 The German Hospital faced debt for several years after rebuilding in the mid-1860s. The position was reversed only by a grand bazaar in 1867 and heightened publicity, which increased voluntary contributions and attracted a large donation of $\mathfrak{1 0 , 0 0 0}$ in 1869 (German Hospital papers, City and Hackney Archive, St Bartholomew's Hospital,
}

Smithfield (hereafter GH papers), Hospital
Committee 1863-1873, A/2/4-5). St Thomas's
Hospital was not so fortunate. Financial problems
dogged it after its forced move to Lambeth, as
resources, hampered by the onset of the agricultural
depression, did not match the expenditure associated
with the new building: L Granshaw, 'St. Thomas's
hospital, London, 1850-1900', PhD thesis, Bryn
Mawr College, 1981, p. 391.

Smithfield (hereafter GH papers), Hospital Committee 1863-1873, A/2/4-5). St Thomas's Hospital was not so fortunate. Financial problems resources, hampered by the onset of the agricultural depression, did not match the expenditure associated hospital, London, 1850-1900', PhD thesis, Bryn Mawr College, 1981, p. 391. 
the 1850 s when they started meeting a growing demand for medical care. ${ }^{17}$ Development varied considerably between institutions. For example, the London Hospital, at the centre of poverty in the East End, and Guy's, one of the few hospitals south of the Thames, grew at a faster rate than their counterparts in the medically overcrowded districts of central London. Outpatient treatment had few constraints on expansion, and required minimal investment in buildings or resources. All serious and interesting cases were admitted directly to the wards and the remaining patients were treated rapidly, so that increased numbers could be seen. Historically this expansion can be explained by developments in medicine, particularly surgery and nursing, which encouraged the public to alter their perception of institutional medicine. ${ }^{18}$ Hospitals built on their new popularity by issuing pamphlets showing pleasant wards, flowers and uniformed nurses to increase the impact of their charitable appeals. The result was a rapid rise in admissions as hospitals came to be seen as a practicable location for medical care. The growth of the Metropolitan Hospital Saturday Fund, a working-class collection scheme founded in 1873, compounded this increase. The Saturday Fund, in encouraging contributions from the artisan elite, raised the hospitals' profile and stimulated the view that contribution gave an entitlement to treatment and representation on the hospitals' management committees. ${ }^{19}$ The Fund was too preoccupied with its own fund-raising problems to become much involved in the outpatient debate, but in collecting money from the working classes it unwittingly encouraged a greater use of outpatient departments. Governors equally needed "to make a goodly show of work in the eyes of the public, with the object . . . of attracting subscribers" and therefore encouraged growth. ${ }^{20}$ Admissions played an important role in hospital appeals and governors played on patient numbers as an aggregate of their institution's utility. Hospitals rested precariously between their financial constraints and the need for more patients.

This was not how contemporaries perceived developments. James Pollock, writing to The Times in 1871, expressed a view that was to become common:

the social condition of a large number of those attending was observed to be far removed from poverty, and such as scarcely to permit their being regarded as legitimate objects of gratuitous relief. Persons provided with governors' orders, but belonging to the comfortable, and even occasionally to the richer classes, thus occupied the valuable time of a hard working medical attendant and interfered with the relief of the truly deserving ... Some by an annual guinea subscription, become

\footnotetext{
${ }^{17}$ Loudon, op. cit., note 12 above, p. 974.

${ }^{18}$ For example see S J Reiser, Medicine and the reign of technology, Cambridge University Press, 1978, for the rise of clinical technology. For the growth of specialism and the change in therapeutic and surgical practice see R Stevens, Medical practice in modern England: the impact of specialization and state medicine, New Haven, Yale University Press, 1966; A Youngson, The scientific revolution in Victorian medicine, London, Croom Helm, 1979, and C Lawrence, 'Incommunicable knowledge', $J$. Contemp. Hist., 1985, 20: 503-20, for a more conflict based analysis. F B Smith, Florence Nightingale: reputation and power, London, Croom Helm, 1982, and B Abel-Smith, A history of the
}

nursing profession, London, Heinemann, 1960, offer accounts of the professionalization of nursing. For the nursing sisterhoods see J Moore, A zeal for responsibility, Athens and London, University of Georgia Press, 1988; A Summers, 'The mysterious demise of Sarah Gamp: the domiciliary nurse and her detractors', Vic. Stud., 1988/89, 32: 365-86, and C Helmstadter, 'Robert Bentley Todd, Saint John's House, and the origins of the modern trained nurse', Bull. Hist. Med., 1993, 67: 282-319.

$19 \mathrm{~J}$ Brand, Doctors and the state, Baltimore, John Hopkins Press, 1965, p. 193.

${ }^{20} \mathrm{M}$ Mackenzie, 'The use and abuse of hospitals', Contemp. Rev., 1890, 58: 501-19, p. 507. 


\section{The Debate over Outpatient Admissions to London Hospitals}

governors and nominate themselves as patients. Others give their orders indiscriminately to persons who may be their dependants, but who are well able to enumerate their medical attendants, and thus the large class of general practitioner is defrauded. ${ }^{21}$

The rapid and obvious growth of outpatient departments alerted contemporaries to the position of "gratuitous medical assistance". Feelings were divided as to its degree. In 1887 the Hospital, a journal for hospital philanthropists, conceded that "when we come to discuss how much abuse there is, there arises great differences of opinion". 22 The Lancet initially believed that conditions in outpatient departments were too appalling to appeal to "well-todo" patients, but by 1886 it had modified its opinion. The editor now felt that "it is a notorious fact that hospital relief is confessedly no longer restricted to persons altogether destitute. Indeed, the majority of metropolitan out-patients are comparatively well-to-do". ${ }^{23}$ Timothy Holmes, treasurer of St George's Hospital, claimed that more than one million were receiving free medical care in London. ${ }^{24}$ Holmes's assessment was an exaggeration, although not the most outlandish. Others offered conflicting opinions. The secretary of the Great Northern Hospital explained that "cases of gross imposition are, I am sure, very rare, and a great deal too much has been made of them", a view shared by the organizers of the Hospital Saturday Fund. ${ }^{25}$ Surveys differed. Each adopted its own assessment criteria and relied on impressionistic evidence in the absence of accurate records. Many accounts of abuse listed individual cases where patients were believed to be wearing clothes that were too smart for their expected social status, preferring such criteria to anything more precise. An informal committee on abuse established by members of the Royal Medical and Chirurgical Society in 1869, recommended after considerable deliberation that patients with a weekly income of more than $£ 110$ s should "be expected to belong to a sick club or provident dispensary". ${ }^{26}$ The COS was harsher. According to the Society's investigation at the Royal Free Hospital in 1875 only 36 per cent of the patients had been suitable candidates for admission. ${ }^{27} \mathrm{~J}$ Steele, medical superintendent at Guy's, when investigating thirteen London hospitals in 1878 , was more realistic. He found that while many patients could possibly contribute to a provident scheme, the general feeling was that the hospitals were not "materially" abused. Steele showed that where patients had had some financial means they had generally already exhausted them in consulting a general practitioner, or were seeking the use of the hospitals' specialist departments for which they would be unable to afford the consultant's fee. ${ }^{28}$ In 1897 the Lancet conducted its own investigation and sixty institutions were polled. Of the fourteen general hospitals asked, nine denied that any abuse occurred and those that acknowledged the problem held that it was "very small indeed". ${ }^{29}$ The Lancet itself was not convinced, maintaining that abuse was widespread. This position reflected the unshakeable view of most contemporaries.

\footnotetext{
$21 \mathrm{~J}$ E Pollock, 'Abuse of hospital relief', The Times, 25 May 1871, p. 10.

${ }^{22}$ Editorial, Hospital, 2 July 1887, p. 237.

${ }^{23}$ Cited in E Moberly Bell, The story of hospital almoners, London, Faber and Faber, 1961, pp. 19-20; 'Hospital reform', Lancet, 1881, ii: 555.

${ }^{24}$ COS pamphlet, Outpatient reform, London, s.n., n.d.

25 'Hospital out-patients', Charity Organisation Reporter, 13 Oct. 1881, p. 190; Hospital Saturday
}

Fund Journal, March 1894, p. 4.

${ }^{26}$ Abel-Smith, op. cit., note 4 above, p. 106.

${ }^{27} \mathrm{C} \mathrm{S}$ Loch, Cross purposes in medical reform, London, s.n., 1884

$28 \mathrm{~J}$ Steele, Summary of information relative to the working of the out-patient departments in thirteen London hospitals, London, s.n., 1878.

${ }^{29}$ Thomas Wakley, 'Metropolitan Hospital Sunday Fund and the Hospital Reform Association', Lancet, 1897, i: 1657. 


\section{Keir Waddington}

"To say that we do not relieve a certain percentage who are not deserving of it", noted Sir Sydney Waterlow, treasurer of St Bartholomew's Hospital, "would be saying too much" ${ }^{30}$ It was an axiom that could be widely applied. Contemporaries claimed that abuse existed, but found it difficult to prove. The absence of outpatient records prevents an accurate analysis of the extent of abuse, but an indication can be gained through a study of surviving inpatient records as most inpatients were admitted through the outpatient department. I have used Joseph Banks's work on the occupational structure of the nineteenth century to provide a rough analytical framework to measure the social class of admissions. He studied the categories used in the 1911 Census and found that they were the most reliable guide, as they reflected the element of superiority-inferiority implicit in a class structure. By applying Banks's categories, which break society down into five stratified classes (I to $\mathrm{V}$ ), it is possible to produce a rough picture of outpatient admissions. ${ }^{31}$ An analysis of admissions to St Bartholomew's, Guy's and the German Hospital, and surgical cases at the London Hospital, suggests that there was no sudden influx of the type of patients contemporaries felt could afford to pay for their care. Voluntary hospitals retained their working-class character, a view confirmed by Lindsay Granshaw in her study of St Thomas's. ${ }^{32}$ The COS itself reluctantly admitted that at the London Hospital little abuse had been detected. ${ }^{33}$ Guy's shows this development clearly. In 1855 , of the 4,063 cases admitted, 300 ( 7.4 per cent) came from classes I and II, Banks's top two groups (see Table 2) ${ }^{34}$ The pattern of occupations by 1890 , if more diverse, maintained its working-class orientation: classes I and II now represented 7.9 per cent of admissions. ${ }^{35}$ Whether these working-class patients were deserving of treatment and had an economic position to justify charitable assistance must remain uncertain; even contemporaries had difficulties in defining what the term "deserving" really meant. Most patients had few alternatives to hospital care outside the Poor Law, as their wages were often too low to pay a general practitioner, let alone an elite hospital consultant. Patients did contribute something towards the cost of care when they were asked to pay for their medicines, but as the charges for these were generally between 1d. and 3d. this should not suggest that they were undeserving. However, the very existence of outpatient departments where accidents were received ensured that London's hospitals could never be only for the working classes. For the London Hospital this situation was magnified by its location in the East End and the pressure of numbers ensured that only accident and emergency cases were admitted. Specialist departments attracted those who could not afford consultants' fees, and doctors used outpatient departments to get past the

\footnotetext{
${ }^{30}$ Select Committee of the House of Lords on Metropolitan Hospitals, etc., Ist report, PP, 1890, xix: p. 172.

31 J A Banks, 'Social structure of nineteenth century England as seen through the census', in $\mathbf{R}$ Lawton (ed.), The census and social structure, London, Cass, 1978, pp. 179-223.

${ }^{32}$ St Bartholomew's Hospital Archive, City and Hackney Archive, St Bartholomew's Hospital Smithfield (hereafter SBH Archive), statistical tables of patients under treatment, MR/9/62; MR/9/84; German Hospital annual reports; Guy's Hospital Archive, Greater London Record Office (hereafter
}

\author{
Guy's Archive), patient records, H9/Gy/B2/1,5; \\ Gy/B3/1,7,12; Gy/B25/2; London Hospital Archive, \\ Royal London Hospital Library and Museum \\ (hereafter LH Archive), register of operations \\ 1852-1862, M/3/74; Granshaw, op. cit., note 16 \\ above, pp. 62-7. \\ ${ }^{33}$ LH Archive, house committee minutes \\ 1876-1878, A/5/38. \\ ${ }^{34}$ Guy's Archive, patient records 1855 , \\ H9/Gy/B2/1. \\ ${ }^{35}$ Guy's Archive, patient records 1890 , \\ H9/Gy/B2/5; B3/12.
}


Table 2

Banks's Classification Scheme

\begin{tabular}{|c|c|c|}
\hline Class & Classification & Occupations (sample) \\
\hline I & Professional Occupations & $\begin{array}{l}\text { Clergy, Clerks, Law, Medicine, Property Owning, Public } \\
\text { Service, Teaching, etc. }\end{array}$ \\
\hline II & Intermediate Occupations & 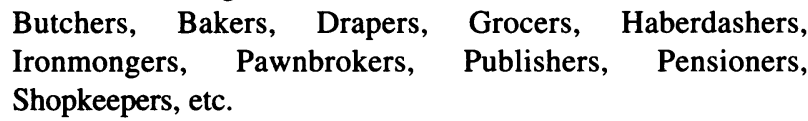 \\
\hline III & Skilled Occupations & $\begin{array}{l}\text { Bricklaying, Carpenters, Domestic (indoor), Footwear } \\
\text { Manufacturers, Gunsmiths, Hairdressers, Instruments, Printing, } \\
\text { Plasters, Plumbers, Seaman, Tailors, Waiters, Wheelwrights, } \\
\text { etc. }\end{array}$ \\
\hline IV & Semi- Skilled Occupations & $\begin{array}{l}\text { Agriculture, Brewers, Coopers, Domestic (outdoor), } \\
\text { Fishermen, Furriers, Laundry Workers, Machinists, Millers, } \\
\text { Postmen, Sculptors, Tanners, Turners, Warehousemen, etc. }\end{array}$ \\
\hline V & Unskilled Occupations & $\begin{array}{l}\text { Bargemen, Cabmen, Costermonger, Labourers, Mining, } \\
\text { Porters, Sugar Refiners, etc. }\end{array}$ \\
\hline
\end{tabular}

Source: J A Banks, 'Social structure of the nineteenth century as seen through the census', in $\mathbf{R}$ Lawton (ed.), The census and social structure, London, Cass, 1978, pp. 203-23.

restrictions placed on admissions by governors. ${ }^{36}$ This served to modify the hospitals' working-class character. Middle-class patients were admitted and their numbers gradually increased as a reflection of the hospitals' modified image. Nevertheless, they were not so great as to alter the hospitals' character or to justify the perception of contemporaries that outpatient abuse was widespread.

An abuse of charity was discerned in London's outpatient departments because it was convenient to link a rise in admissions to an influx of undeserving patients rather than to admit that hospitals were developing a real medical function that was at odds with their original philanthropic criteria. Within the resulting debate, the problem was transferred from the voluntary system that had promoted expansion, to the individual. It was not the celebrated British habit of voluntarism that was seen as harmful, but a misapplication of charity. To challenge benevolence would question the tenets that underpinned much of the informal Victorian welfare provision and raise uncomfortable and unwelcomed issues about the role of the state. ${ }^{37}$ Philanthropists could believe that the "absence of a crusade" against the "demoralising and damaging" practices of outpatient departments had multiplied these problems. ${ }^{38}$ Criticism of hospital management escalated and the debate over outpatient abuse provided a platform through which an argument for reform could be

\footnotetext{
36 J Woodward, To do the sick no harm, London, Routledge \& Kegan Paul, 1974, provides an accurate assessment of the types of patient hospitals admitted, though broadly they tried to exclude those cases with high mortality rates.

${ }^{37}$ See $P$ Thane, 'Government and society in England and Wales, 1750-1914', in F M L
}

Thompson (ed.), The Cambridge social history of Britain, 1759-1950, III, Social agencies and institutions, Cambridge University Press, 1990, pp. $1-62$.

${ }^{38} \mathrm{H} \mathrm{C}$ Burdett, Hospital and asylums of the world, 4 vols, London, Churchill, 1891-93, vol. 3, p. 220. 


\section{Keir Waddington}

constructed and legitimized. Doctors took up the issue precisely on these terms in an attempt to reorient the hospital to their own professional interests.

\section{The Debate}

The medical profession led the debate and, even if internal grievances between factions were not put aside, all sections condemned the perceived existence of abuse. In 1869, the Lancet, determined to find the extent of abuse, organized a commission to investigate. The investigation showed clearly that reform was necessary because overcrowding had increased with patient numbers. Following these disclosures the Royal Medical and Chirurgical Society convened a public meeting in 1870 . This was attended by 150 doctors and, after a heated debate, it established an informal committee to study the problem. ${ }^{39}$ The committee, named after its chairman the surgeon Sir William Fergusson, was seen as "influential" and provided a catalyst for discussion that invigorated the medical profession. As Smith notes in The people's health, "the notions that outpatients' departments had become 'unmanageable' and that their facilities were 'greatly abused' became increasingly attractive to doctors .... 40 The committee did not, however, represent the entire medical profession, and its interests remained firmly focused on the London hospitals. It appointed three subcommittees to investigate the capital's general and specialist hospitals and dispensaries respectively; no mention was made of establishing a subcommittee to study the impact on general practice. This was not surprising; out of thirty-seven members, thirty-two held lecturing or medical appointments in the capital's hospitals. Only two were physicians at dispensaries and there was only one medical officer of health and one representative from the Poor Law Medical Officers' Association. All the teaching hospitals were represented except Charing Cross Hospital, while the Middlesex Hospital, with four members, had the largest representation. Not every specialism was covered, most of the specialists being drawn from hospitals for women and children, diseases of the eye, orthopaedics, and consumption. Given Fergusson's background as one of the leading surgeons in London and professor of surgery at King's College Hospital, surgeons out-numbered physicians sixteen to twelve. ${ }^{41}$ The composition of the committee effectively showed that an attack on London's outpatient departments was an attempt to reconstruct hospital doctors' working environment.

Doctors were far from unanimous on the extent of abuse, but they managed to conceal professional differences by emphasizing the moral problems of outpatients' admissions. ${ }^{42}$ Fergusson, speaking for the 1870 committee, announced that the profession had a "duty" to the benevolent public to prevent charity from being "misdirected". ${ }^{43}$ Members of the committee followed his example with a rhetoric that firmly emphasized the public good of their investigation rather than professional self-interest. Warning against the habit of dependence, the committee saw a consultative role for outpatient departments and called for greater co-operation with the Poor Law, an end to hospital letters, and the development of provident dispensaries. It emphasized throughout that it was trying to limit the abuse of

39 'Hospital Reform', Br. med. J., 1897, ii: 1272-7, p. 1274.

${ }^{40}$ F B Smith, The people's health 1830 to 1910 , London, Croom Helm, 1990, p. 278.

41 'Outpatient administration reform', Lancet,
1870, i: 497; 500.

42 'Hospital abuse', Br. med. J., 1898, i: 993.

43 'Outpatient administration reform', Lancet, 1870 , i: $497-500$, p. 498. 


\section{The Debate over Outpatient Admissions to London Hospitals}

charity rather than protect private practice or restructure outpatient departments so as to limit the work undertaken by hospital doctors. ${ }^{44}$ Purely professional concerns came at the end of its report when the committee recommended that doctors should spend no more than three hours working in outpatient departments. ${ }^{45}$ This proposal was adopted by other doctors. According to Dr R Hill Shaw, the profession was waging "war not against charity but against the meanness of a large section of the public who 'sponge' on the kindly aid which is voluntary and charitably contributed to help in sickness the deserving poor and needy man's misfortune". ${ }^{46}$ Outpatient departments were shown to be encouraging pauperism by introducing patients to the demoralizing habit of charity. Some believed that "indiscriminate relief encouraged people to be sick", reducing the strength of the nation. ${ }^{47}$ These were powerful images in a society acutely embarrassed by the extent of poverty and preoccupied with health and notions of character. ${ }^{48}$

Doctors, however, were motivated by other, less altruistic concerns. It was widely understood within all sections of the medical profession that "the combined attraction of a great name and of gratuitous relief" had produced an intolerable situation. ${ }^{49}$ Doctors attacked friendly societies and contract practice with the same rhetoric, and complaints that practitioners were placed at a disadvantage were regularly repeated throughout the medical press. ${ }^{50}$ For Squire Sprigge, outpatient abuse was second only to the evils of contract practice and so a vital professional concern at the start of the twentieth century. ${ }^{51}$ Others constructed the problem as the cause of "unnumbered woes" and removed the blame from those working in London's hospitals. ${ }^{52}$ Conditions were often appalling, and doctors were overworked in an environment that Frederick Treves, surgeon at the London Hospital, described as "cold" and "harsh"; where patients were not above bribery and violence to ensure that they were seen first. ${ }^{53}$ Whereas advice and treatment were the main reasons for visiting a hospital, and stress was placed on the superior skills of the hospitals' medical staffs, outpatients came

in such numbers that it is impossible for any medical man to see them all properly in the allotted time: hence the great majority are asked a few hasty questions, hurriedly examined, and ordered medicine; and on their later visits seen even faster, and often by a different person. ${ }^{54}$

This was felt to be an affront to doctors' professional status, reducing their claims to utility and cure, but at the same time providing a valid excuse for any "scamping of duty". Many argued that hospital doctors were simply too overworked to provide the care they aspired to. ${ }^{55}$ It was estimated in 1890 that at most large general hospitals the medical staff were expected to see approximately 120 outpatients an hour. ${ }^{56}$ In the Lancet's opinion "the $135-7$

44 'Hospital out-patient reform', Lancet, 1870, ii:

${ }^{45}$ Ibid., pp. 199-200. i: 82

${ }^{46}$ R Hill Shaw, 'Hospital reform', Lancet, 1897,

47 'Outpatient administration reform', Lancet, 1870, i: 497-500.

${ }^{48}$ See Collini, op. cit., note 10 above, pp. 91-118, and G Himmelferb, Poverty and compassion: the moral imagination of the late Victorians, New York, Alfred A Knopf, 1991.

49 'Out-patient departments in hospitals', Lancet,
1869 , ii: 482.

50 Green, op. cit., note 5 above, p. 83.

51 Sprigge, op. cit., note 7 above, p. 57.

52 'Our out-patient system', Med. Times Gaz., 1870 , i: 365.

${ }^{53} \mathrm{~F}$ Treves, The elephant man and other reminiscences, London, Cassell \& Co., 1923, p. 41.

54 'Out-patient reform', Med. Times Gaz., 1878, i: 538.

55 Sprigge, op. cit., note 7 above, p. 59.

56 Select Committee on Metropolitan Hospitals, lst report, PP, 1890, xix: p. 7. 


\section{Keir Waddington}

arrangements and accommodation are so inadequate to the number of patients that quality in treatment is necessarily sacrificed to quantity". ${ }^{57}$ Such were the numbers attending two of London's hospitals that "refreshment bars" had to be provided and many appeared willing to wait up to six hours. 58

The press of numbers presented problems for the attendant medical staff. Overcrowding aroused fears of contagion at a time when "hospitalism" was widespread, and the Medical Times and Gazette argued that work in outpatient departments adversely affected doctors' health. ${ }^{59}$ Complaints were made that the work was too exhausting, but most doctors were motivated by other interests. Hospital medical staff were undoubtedly overworked, seeing hundreds of cases without charge each day, and this detracted from the time that could be spent on private practice. Hospital appointments were rarely salaried and only a nominal honorarium was attached to them, as it was argued that an appointment gave "professional status" and "often leads to large and lucrative practices". ${ }^{60}$ A large private practice was therefore crucial to financial security. Where it was perceived that hospital patients could afford to pay for their treatment, doctors felt that they had been taken advantage of and the profession's economic basis undermined. In an overcrowded and status-conscious medical profession these material concerns were important, ${ }^{61}$ and were keenly felt by general practitioners. They argued that hospitals were much too free with their services, and patients who could afford to pay joined hospitals' outpatient queues, injuring the practitioners" "dignity" and "curtailing [their] income". ${ }^{2}$ General practitioners feared that they might become "hall porters" or "turn Medical Tradesmen" in the face of this unfair competition. ${ }^{63}$ At times of distress, as in the mid-1880s when the number of medical scandals increased dramatically, the deleterious effect of outpatient departments on the income of general practitioners seemed particularly relevant.

This perception of unfair competition among the profession's rank-and-file created a tension with those working in hospitals was not easily resolved. Sir Edward Sieveking, consultant physician at St Mary's Hospital, expressed an opinion common among hospitals' medical staff that outpatient departments were important medical resources and vital for education. ${ }^{64}$ Specialists argued that hospitals needed large flows of clinical material to maintain their reputation. However, a dilemma existed between this requirement and the awareness that large numbers "made the teaching bad", with clinical resources being wasted and too much time being devoted to cases that were of no educational interest. ${ }^{65}$ Hospital doctors could therefore join with general practitioners in an attack on outpatient departments because their skills were being wasted on trivial cases, and senior hospital men felt that the rapidity of treatment was undignified. It was an

\footnotetext{
57 'St. Bartholomew's Hospital', Lancet, 1869, ii: 240.

58 'Out-patients at metropolitan hospitals', Charity Organisation Reporter, 13 Nov. 1879, p. 245; Charity Record and Philanthropic News, 1898, 18: 380 .

${ }^{59} \mathrm{C}$ E T, 'Out-patients departments of hospitals', The Times, 6 May 1878, p. 11; A health officer, 'Our hospital system', Med. Times Gaz., 1861, i: 401.

60 'London hospitals and dispensaries', The Times, 30 Jan. 1869, p. 4.

${ }^{61}$ See A Digby, Making a medical living:
}

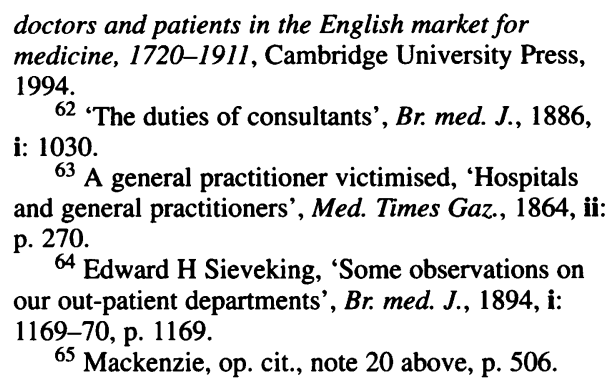




\section{The Debate over Outpatient Admissions to London Hospitals}

uneasy alliance that was periodically disturbed by savage attacks from general practitioners who felt that their livelihoods were under threat. Common ground was found in the limitation of admissions, which appeared to address the broad spectrum of professional concerns without challenging the voluntary system.

Hospital doctors and general practitioners were not the only sections of society interested in abuse. The subject was

fully discussed from time to time by the ... Social Science Association, the BRITISH MEDICAL JOURNAL and the Lancet, as well as in the columns of the daily press, so that a variety of persons interested either as doctors, philanthropists, or hospital officials, have had an opportunity of ventilating their ideas upon it. ${ }^{66}$

Philanthropists took up the problem once the Fergusson Committee had defined the agenda. The publicity surrounding the committee pushed the issue into the public domain and it became a matter of periodic public debate. The main vehicle for philanthropic concern was the COS. Its statements dominated and characterized lay discussion on abuse, rivalling the interest shown by the medical profession. For the COS "there could be no doubt that the number of unworthy recipients of hospital relief . . . was fast increasing, and the moral influence of this was of very great public importance". 67 The existence of outpatient abuse confirmed the Society's fears that a moral deterioration was spreading across London as charitable agencies were fooled by a pauperized poor. The COS aimed to promote "the transformation of a charitable chaos into an orderly and friendly neighborhood [sic], in which rich and poor consult together and unite their resources". ${ }^{68}$ This was to be achieved through the organization of charitable effort and "cooperation between Charities and the Poor Law, and amongst the Charities". ${ }^{69}$ The condition of the poor was not blamed on the nation's socioeconomic structure, but on the poor's "own improvident habits and thriftlessness". ${ }^{70}$ The Society undertook a prolonged struggle to control various aspects of social reform, aiming to attack pauperism through the promotion of providence, thrift and industry within an ethos that emphasized the importance of character. ${ }^{71}$ Outpatient abuse was therefore enthusiastically seized upon as part of the COS's campaign to eliminate "from society those animals who represented themselves to be men, but who really were nothing more than animals grovelling in the earth and mire, living on the bread of idleness". ${ }^{72}$ It contained all the problems that the COS sought to redress and the Society's efforts over the issue fitted within its general critique of philanthropy and its argument for organization and investigation.

Sir Charles Trevelyan, an ex-Treasury official and the Society's main spokesman on the issue, described outpatient abuse as a problem that affected the very morale of society. ${ }^{73}$ The COS argued that

\footnotetext{
${ }^{66} \mathrm{H}$ Nelson Hardy, contribution to 'A discussion on the abuse of the out-patient departments of hospitals', Br. med. J., 1896, ii: 370-5, p. 373.

67 'Hospital Out-Patient Reform Association', Charity Organisation Reporter, 12 March 1873, p. 43.

68 B Bosanquet, 'The principles and chief dangers of the administration of charity', in $\mathbf{J}$ Addams, et al. (eds), Philanthropy and social progress, Boston, T Y Crowell, 1893, p. 257.

${ }^{69}$ Manual of the Society for Organising Charitable Relief and Repressing Mendicity, objects
}

and mode of operation, London, s.n., 1870, p. 7.

${ }^{70}$ Charity Organisation Reporter, 24 Feb. 1881, p. 50.

${ }^{71}$ See J Harris, Unemployment and politics. A study in English social policy, 1886-1914, Oxford University Press, 1972, p. 106.

72 'Annual meeting', Charity Organisation Reporter, 26 March 1873, p. 55.

73 'Hospital out-patients', The Times, 8 March 1873, p. 10. 


\section{Keir Waddington}

the crowd of patients is not useful for purposes of medical teaching; it is injurious to the general practitioner, who but for the free treatment provided at the hospitals would obtain from many of them fees charged at a low rate ... and it is injurious to the patients themselves, who instead of making provision against sickness ... become accustomed to dependence on others for medical relief, and often subsequently, for chronic help. ${ }^{74}$

It was therefore not surprising that hospitals had continually to appeal for funds in a climate where they being forced to treat patients of an unsuitable character. The COS castigated outpatient departments as debilitating, pauperizing, and damaging to doctors, but their main fear was that free medical treatment would be the start of "temptations to begin a life of dependence on charity or of pauperism". ${ }^{75}$ It was a view widely held among philanthropists.

In 1871, at a conference held at the Society of Arts, the COS established a medical subcommittee to "deliberate and advise on medical charities" and announced its intention to support hospitals in limiting abuse. ${ }^{76}$ Enthusiasm quickly waned and the committee met infrequently after 1871 , but the issue provided a constant source of discussion. ${ }^{77}$ Initially attempts were made to organize conferences on the subject, but the public's hostility to the COS prevented concerted action. The approach was modified in the 1880 s when Colonel Montefiore took over the chair of the subcommittee. Governors and their medical staff were now canvassed directly. In 1886 the secretary made 406 visits to seventy-one medical institutions, although in the following year canvassing was decentralized to the Society's District Committees as part of a general effort to encourage co-operation between hospitals and charity. ${ }^{78}$ The COS also followed its own rhetoric and started working with the various organizations set up to promote reform. ${ }^{79}$ Throughout, its interest remained dogmatic and its moral enthusiasm helped mitigate against setbacks.

The debate also inspired the formation of several organizations that combined medical and philanthropic interests. They repeated the accepted dogma of abuse, helping to extend the debate into discussions focusing on the need to reform the voluntary medical system. However, they did not have the same impact on hospital management. Organizations established specifically to counter abuse, like the Hospital Outpatient Reform Association launched by general practitioners in 1873 , invariably proved stillborn. ${ }^{80}$ The BMA, according to Loudon, was no more successful. ${ }^{81}$ The Association established a special subcommittee to further outpatient reform and incessantly agitated for improvement, but most governors remained unconvinced by its arguments. The Hospital Reform Association, founded in 1896 after twenty-six years of agitation, was more effective, despite the Hospital's accusation that it used old programmes under "new names". 82 It was helped by an increased interest in hospital reform after the proceedings of the House of Lords' Select Committee on Metropolitan Hospitals had been published. ${ }^{83}$ The

\footnotetext{
${ }^{74}$ COS annual report, 1896, p. 21.

$75 \mathrm{C}$ Trevelyan, Metropolitan medical relief, London, s.n., 1879, pp. 3-5; COS 1878 annual report, p. 19.

76 'Outdoor hospital relief', Br. med. J., 1871, ii:

${ }^{77}$ COS papers, Greater London Record Office, medical subcommittee 1871-1896, FWA/A26/1-9.

${ }^{78}$ COS annual reports, 1886, p. 50; 1887, p. 28.
} 705-6.

\footnotetext{
${ }^{79}$ COS Archive, Greater London Record Office, medical subcommittee 1884-1886, FWA/A26/3.

80 'Hospital out-patient reform association', Med. Times Gaz., 1873, i: 240-1.

${ }^{81}$ Loudon, op. cit., note 11 above, p. 976.

${ }^{82}$ Editorial, Hospital, 31 Oct. 1896, p. 73.

83 Select Committee on Metropolitan Hospitals, 2nd report, PP, 1890/1, xiii; 3rd report, PP, 1892, xiii.
} 


\section{The Debate over Outpatient Admissions to London Hospitals}

Association, as a revival of the Fergusson Committee, "sought to concentrate medical opinion upon the question of the reforms which were needed in hospital administration", but also served to unify interest groups disaffected with the voluntary system. ${ }^{84}$ The debate over outpatient abuse formed a major part of its activities. The Association took a firm stand on trivial cases, but some of its members regarded this as erroneous, claiming that patients were unable to define their own illnesses. ${ }^{85}$ The Association, however, felt that it had made some headway, despite internal conflict. Constant agitation ensured that governors established their own subcommittees, as at University College Hospital in 1898 , to investigate their outpatient departments. ${ }^{86}$ Reform was harder to secure.

\section{A Programme of Reform}

In 1893 the British Medical Journal noted that, despite lengthy agitation and the many acknowledgements of abuse, there had been no real attempt to work out a systematic plan to resolve the problem. ${ }^{87}$ By 1898 the Lancet had come to argue that it was reform that was important, not the nature of that reform, as it would save hospitals "the suspicion which attaches itself to all undiscriminating forms of relief" 88 Governors were reluctant to limit admissions. However, the fear that "the philanthropic public will cease to tax themselves to support a system so demoralising and so conducive to pauperising undeserving persons", pushed many into action. ${ }^{89}$ For once the governors deferred judgement. They claimed that the issue was "a medical question . . . [that] ought to be guided by the general feeling of the medical profession".90 By using a medical justification for their actions, governors hoped to avoid the censure that a restriction of subscribers' rights would entail. This gave doctors an unrivalled sphere of action where their influence was otherwise limited. Doctors had defined the nature of the debate, and it was the hospitals' medical staff that were most active in ensuring that patient numbers were limited. Many solutions did not originate from those sections of the medical profession working in hospitals, but once announced they readily found medical adherents that gave them a professional justification.

The Fergusson Committee's report in 1870 set out a most comprehensive and progressive programme to meet abuse. Building on advanced notions of co-operation between state welfare and voluntarism, it linked the prevention of abuse to an improvement in the Poor Law. It suggested that all free dispensaries should be placed under the control of the Poor Law Board. This would ensure that all requests for medical relief could be investigated under the existing framework of the relieving officers. Provident dispensaries were to be established "to encourage a feeling of self-respect among the working-classes". Patient numbers were to be restricted on two criteria: the first was on clinical grounds to aid medical education, ensuring that only cases of clinical

\footnotetext{
84 'Hospital reform', Br. med. J., 1897, ii: 1272-7, p. 1272.

85 W P Herringham, 'Hospital Reform Association', The Times, 6 Jan. 1897, p. 8.

${ }^{86}$ University College Hospital Archive, D.M.S Watson Library, University College London (hereafter UCH Archive), subcommittee on inquiry officers 1898, A1/5/2.
}

\footnotetext{
87 'Abuse of medical charities', Br. med. J., 1893, ii: 198

88 'Charity Organisation Society and medical relief', Lancet, 1898, ii: 1143-4.

${ }^{89}$ Nemo, 'Out-patients departments', Med. Times Gaz., 1871, ii: 541 .

90 'Hospital reform', Br. med. J., 1897, ii: 1272-7, p. 1273.
} 


\section{Keir Waddington}

interest were admitted; the second was on social grounds, excluding those patients who could pay for their treatment. ${ }^{91}$ The report was endorsed by a poorly attended meeting that merely established a committee to confront the Poor Law Board, medical charities and the COS. The British Medical Journal wanted more action, criticizing the Committee for its "amateurish" approach. Hospital doctors and general practitioners remained unenthusiastic: when asked to contribute to the cost of publishing the report they donated only $12 \mathrm{~s} 6 \mathrm{~d} .{ }^{92}$ However, the report encouraged an extension of the debate and provoked a more detailed investigation of the possible solutions to abuse.

While the Fergusson Commission advocated the most comprehensive programme of reform, other less popular schemes were also put forward. Progressive reformers within the profession felt that outpatient departments should adopt a purely consultative role and some went so far as to suggest their abolition. ${ }^{93}$ The Hospital Reform Association integrated the former suggestion into its campaigning, but the debate remained largely theoretical. An attack on outpatient departments brought into question both their existence and the nature of the voluntary system, encouraging an extension of the discussion into suggestions for a state assisted scheme of medical relief. It was here that the debate started to address wider matters of hospital reform. ${ }^{94} \mathrm{~A}$ key character in this transformation was the physician Robert Reid Rentoul. A general practitioner in Liverpool, Rentoul was an awkward figure, who seemed to delight in involving himself in contentious social and medical debates. ${ }^{95}$ Having won the Sturge Prize with an essay on the 'Financial condition of London hospitals', he continued his interest in hospitals by launching a vitriolic attack on the outpatient system in 1889. Always willing to advocate radical solutions, in the process of his denunciation he called for a "public medical service". 96 An unwavering supporter of the general practitioners' viewpoint, Rentoul argued that abuse revealed the inadequate nature of the voluntary hospitals, suggesting that they be replaced with a state assisted programme of medical relief. The Fergusson Committee had proposed closer cooperation between voluntary hospitals and Poor Law infirmaries, but Rentoul's ideas threatened the very nature of charitable medical care. Others adopted his ideas, which provoked animated discussion for much of 1889 and again in 1896, when the issue of a state medical system reemerged. ${ }^{97}$ Doctors and philanthropists, however, remained generally antagonistic to such avant garde proposals.

91 'Hospital reform', Br. med. J., 1871, i: 458-9.

92 'Hospital organisation', Br. med. J., 1870, ii: 95; Alfred Meadows, 'Out-patient hospital reform', Lancet, 1870, ii: 591.

${ }^{93} \mathrm{~T}$ Garrett Horder, 'An address on hospital reform', Lancet, 1896, ii: 1742-4.

${ }^{94}$ For the debate over metropolitan hospital reform at the end of the nineteenth century see $\mathrm{G}$ Rivett, The development of the London hospital system 1823-1982, London, Oxford University Press, 1986; Abel-Smith, op. cit., note 4 above.

95 For example, after his involvement in the debate over outpatient abuse, Rentoul moved on to turn his interest in obstetrics to the questions of abortion, becoming involved in the discussions surrounding the medical profession and midwifery. He appeared to tire quickly of this debate and started contributing to the eugenics school of argument and the discussion over national efficiency, writing Proposed sterilisation of certain mental and physical degenerates, London, Walter Scott, 1903, which was followed by Race culture, or, race suicide, London, Walter Scott, 1906.

96 Robert R Rentoul, 'Out-patient reform and the public medical service', Br. med. J., 1889, ii: 1067.

${ }^{97} \mathrm{~W}$ Knowsley Sibley in a pamphlet State aided v. voluntary hospitals, Halifax, T Burleigh, 1896, favouring a state led reorganization, as Poor Law infirmaries were free from abuse. Frederick Mouat linked this to a need to rationalize the Poor Law and proposed state aid, linking this to unification and the abolition of the distinctions between Poor Law infirmaries and voluntary hospitals: 'State-aided v. voluntary hospitals', Lancet, 1896, i: 723. 


\section{The Debate over Outpatient Admissions to London Hospitals}

Philanthropists had their own ideas. Governors at the Westminster Hospital suggested the most straightforward solution. They felt that the misapplication of governors' letters promoted abuse and they appointed a subcommittee whose final report called for their discontinuation. ${ }^{98}$ The COS was enthusiastic and a conference of hospital managers in 1879 concluded that the letter system was gradually being abandoned. ${ }^{99}$ This optimism was misplaced. Letters were "ingrained in the voluntary system" and governors were anxious to retain them as they were the prime means of soliciting contributions as a quid pro quo for support. 100 Others suggested a return to the principles of "mutual assistance" through provident dispensaries or patient charges. Both solutions met opposition. Provident dispensaries combined the idea of treatment at home with payment for advice and medicines. They were, however, expensive to establish. Those organizing provident dispensaries could not rely on charitable support and had to provide the initial capital for a building and medical salaries, while their success was not guaranteed. By 1892 thirtyfive existed in London, but many were on a precarious footing. The Clerkenwell Dispensary, for example, was forced to close within a few years of its opening because only the better-off working men subscribed to it, thus defeating its object of treating the poor. ${ }^{101}$ For general practitioners provident dispensaries were no less undesirable than outpatient departments in that they also represented a threat to private practice, while hospital governors refused to sanction an institution that would be in direct competition with their own. Patient payment schemes were more unpopular. The idea received the support of the Home Hospital Association; founded in 1877 to promote institutional treatment for the middle classes, but of the large general hospitals only Guy's and St Thomas's were prepared to set up payment schemes. The BMA remained critical and feared for general practitioners' economic position, while governors shared the opinion "that the more a hospital seeks to help itself out of patients' pockets the less it is helped by others". 102

Doctors, the COS and hospital governors had the same cause, but approached the solution of outpatient abuse from different directions. Philanthropists and the COS, concerned about how much money was being spent and about the moral character of society, supported reforms that attempted to promote providence. Governors wanted to reassure the public without advocating a solution that would bring fundamental change or damage their financial position. Here hospital doctors' concerns and those held by governors crossed. The medical profession used the same rhetoric as the COS, but hid behind it their own concerns of overwork, professional standing and financial insecurity. Doctors were divided and called for differing solutions. General practitioners, seeing the entire voluntary system as a threat, were willing to call for its removal; hospital doctors merely wanted moderate reform so as to improve their position. Few sections within the debate agreed, and discussions were frequently marked by infighting. All sides, however, wanted to limit numbers.

\footnotetext{
98 COS annual report, 1874.

99 'Out-patients at metropolitan hospitals', Charity Organisation Reporter, 13 Nov. 1879, p. 245.

100 'Hospital letters', Br. med. J., 1898, i: 57.
}

101 COS annual report, 1887 , p. 30.

102 Granshaw, op. cit., note 16 above, pp. 373-423; Guy's Archive, court of committees 1879-1883: H9/Gy/A3/10. 


\section{Keir Waddington}

\section{The Inquiry System in Practice}

Medical and philanthropic suggestions contributed to a circular debate and each solution existed simultaneously in the discussion. None of the schemes outlined above seemed entirely satisfactory, arousing anxiety among governors and general practitioners. The inquiry scheme, advocated by the COS, however, was seen as the most acceptable. It aimed to investigate the economic, social and moral background of patients to see if they were deserving of relief, replacing the subjective analysis of patients' dress with a detailed examination. At the centre of the plan was a system of limitation to exclude patients who could afford to pay for their treatment. Criticism of inquiry schemes remained muted. Even Rentoul offered his support, though the British Medical Journal felt that the inquiry scheme was too strained to be effective. ${ }^{103}$ John Syer Bristowe, a prominent hospital reformer, was more critical. He believed that it increased the sick's suffering and was against the "dignity of medicine". ${ }^{104}$ Many doctors disagreed and inquiry schemes received warm support from the medical press and the metropolitan branch of the BMA. Under such a system, hospital doctors could feel that private practice was protected while admissions were reduced to a manageable level. For general practitioners it appeared to promise that all those who could afford to pay would be made to seek care outside the hospital. Hospital governors were equally supportive. Abel-Smith believes that it represented "some not very resolute action" by hospital governors, but it was often as far as they were prepared to go in limiting abuse. ${ }^{105}$ For governors, an inquiry scheme was a moderate reform that could be controlled and did not challenge the hospitals' voluntary principles.

The COS had given its support to the Fergusson Committee, but in 1872 the Society's Council felt "satisfied that nothing but careful inquiry into the circumstances of applicants for hospital out-relief will meet the abuses to which such relief is liable". ${ }^{106}$ The COS campaigned for inquiry in all fields of charitable activity and readily suggested its formula of investigation for medical relief. ${ }^{107}$ St George's was the first hospital to implement the COS's strategy. In 1872 a scheme was set up whereby all patients were asked a number of questions before treatment and all "doubtful" cases were referred to the COS for investigation. ${ }^{108}$ The London Hospital followed with a similar scheme in 1873 and asked the Whitechapel COS to investigate. A preliminary inquiry by the COS at the Royal Free Hospital in 1874, however, did not result in a permanent inquiry official being appointed. At the Hospital for Sick Children, after lengthy negotiations initiated by the hospital's medical staff in 1875, the governors employed the Society to investigate. Dr Charles West, the hospital's founder, wrote to the COS shortly after the scheme was introduced "expressing satisfaction", but discontent quickly followed and the service was modified in 1876 to increase the house surgeons' authority. ${ }^{109}$ Setbacks like that at the Hospital for

\footnotetext{
103 Robert R Rentoul, 'Hospitals and the wageearning classes', Br. med. J., 1889, i: 1199-1200, p. 1199.

104 'Dr Bristowe on the out-patient question', Lancet, 1885 , i: $572-3$, p. 572.

105 Abel-Smith, op. cit., note 4 above, p. 108.

$106 \mathrm{COS}$ annual report, 1872 , p. 6.

${ }^{107}$ For some historians like K Woodroofe, From charity to social work, in England and the United States, London, Routledge \& Paul, 1962, the COS's
}

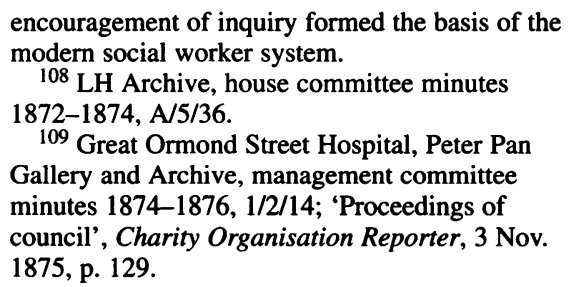
minutes 1874-1876, 1/2/14; 'Proceedings of council', Charity Organisation Reporter, 3 Nov. 1875 , p. 129. 


\section{The Debate over Outpatient Admissions to London Hospitals}

Sick Children did not dampen the COS's enthusiasm, and in 1876 the Society reported that "several hospitals habitually avail themselves of the assistance of the District Committees to enquire into the cases of outpatients". 110

By the 1890s many London hospitals had adopted their own procedures if only to keep out "the frigid influence of the Arctic organization of Buckingham Street". 111 The COS recognized this fact and decided not to be "too scrupulous", anticipating that this would avoid "unjust unpopularity", expressing a realism that was not often acknowledged in its bombastic rhetoric. 112 According to Charles Stewart Loch, the COS's chairman, inquiry was adopted because "the mere knowledge that enquiry was made is said to have greatly reduced the numbers". ${ }^{113}$ Governors saw another benefit. By limiting the number of undeserving patients, income could be saved. The Hospital and the Metropolitan Hospital Sunday Fund, a fund established to distribute an annual collection on the basis of utility, were equally enthusiastic. ${ }^{114}$ From 1897 the Sunday Fund started to discriminate in favour of hospitals that had appointed an inquiry officer, giving a financial incentive to action. ${ }^{115}$

It seems strange that the main impetus to establish an inquiry system came from the hospitals' medical staff. Inquiry theoretically represented an external control on the doctor's authority to determine the suitability of each case for treatment. However, inquiry was rarely as the COS envisaged, even when it was under its control. Even before the COS was allowed to investigate, doctors insisted that all new outpatients had to be seen on their first visit, no matter what their social status. For doctors this ensured that emergency cases were not turned away and interesting cases could be admitted immediately without question. At the Hospital for Sick Children control continued to rest firmly with the doctors. They defined the special circumstances under which an inquiry was not made, and it was the doctors who referred cases to the Society. ${ }^{116}$ When the inquiry officer was not present, the medical staff admitted patients as they saw fit, with no reference to their social background. A similar system existed at St Bartholomew's Hospital. In 1882 the governors appointed an "educated man" as an inquiry officer with an annual salary of $£ 150$ "to take down names and addresses and to ask certain questions of the applicants as they come in; then, if he saw occasion, reference was made to the Charity Organisation Society". ${ }^{117}$ Power, however, was "given to the medical officers on duty to refuse advice and treatment". ${ }^{118}$ Inquiry outside the COS's influence was more liable to have a strong medical bias. The Great Northern Central Hospital had two levels of inquiry: one tested the patient's social position, the other, conducted by a specially appointed medical officer, decided medical suitability. ${ }^{119}$ The maintenance of the doctor's power in determining the scale of investigation ensured that inquiry became a tool to limit the number of cases without a reduction in medical authority. By passing the duty of investigation onto a

\footnotetext{
${ }^{110}$ COS annual report, 1876, p. 11.

111 Abel-Smith, op. cit., note 4 above, p. 117.

112 'Inquiries in hospital cases', Charity

Organisation Reporter, 5 April 1876, p. 70.

${ }^{113} \mathrm{C}$ S Loch, 'The confusion in medical charities', Nineteenth Century, 1892, 32: 302.

${ }^{114}$ For the development of the Sunday Fund see $\mathrm{K}$ Waddington, “"Bastard benevolence”: centralisation, voluntarism and the Sunday fund 1873-1898', Lond. J., 1995, 9: 151-67.
}

\footnotetext{
115 Edmund Hay Currie, 'Hospital reform', The Times, 6 Nov. 1897, p. 14.

116 GOS Archive, management committee minutes $1874-1876,1 / 2 / 14$.

117 Select Committee on Metropolitan Hospitals, 2nd report, PP, 1890/1, xiii: p. 457.

118 SBH Archive, governors' minutes 1879-1885, $\mathrm{Ha} / 1 / 25$.

119 'Hospital abuse and its prevention', Br. med. J., 1897, i: 1052-3, p. 1052.
} 


\section{Keir Waddington}

special officer, doctors were spared the unsavoury job of investigating patients' social background and fulfilled their aims of restricting admissions while avoiding additional work for themselves.

Inquiry officers were increasingly seen as a short-term solution. A lack of enthusiasm for the scheme ensured that admissions soon began to increase, and by the 1890s the COS had modified its views. Now it argued that a trained hospital almoner, under its responsibility, would avoid many of the problems encountered with the existing system. ${ }^{120}$ The Select Committee on Metropolitan Hospitals had offered its support in its final report and the King's Fund was to reaffirm the principle in 1910. ${ }^{121}$ An almoner had essentially the same function as an inquiry officer. However, they were expected not only to evaluate outpatients' circumstances but also to help them find the appropriate relief agency if this was not the hospital. The first almoner, Mary Stewart, an experienced COS worker and secretary of the North St Pancras District, was appointed at the Royal Free Hospital in 1895. Initially, Stewart was seconded to the Royal Free for three months, with her salary paid by the COS. Her presence was at first regarded with suspicion by the medical staff who refused to send any patients to her, but gradually this situation changed. Stewart's probation proved successful and admissions decreased, but there was an interval of six months before she returned to the hospital. ${ }^{122}$ During this period the Royal Free debated the financial aspects of the scheme until two members of the COS's medical subcommittee broke the deadlock and donated money to pay her salary. ${ }^{123}$ The Westminster Hospital, without consulting the COS, and St George's Hospital quickly followed and appointed lady almoners in 1899 and 1901 respectively. ${ }^{124}$

Prochaska has argued that governors cynically appointed lady almoners so that they could avoid the "accusation of providing treatment free to all those who could afford to pay for it". 125 Despite initial suspicion, demand grew and other hospitals followed the Royal Free's lead. By 1903 seven London hospitals had almoners and interest was aroused in the provinces. All were female and women continued to dominate. Contemporaries believed that the system allowed patients to make full use of the medical care available and the early almoners helped to provide a network of care by establishing close links with parish clergy, charities and general practitioners. The COS was proud of its initiative and felt that the almoner system was one of their most sturdy "off-spring". Initially, officers were untrained and only aimed at detecting cases of fraud, but, after early experiments the COS appointed a special committee to train almoners so that they were indoctrinated with the Society's ideology. At the same time, Edith Mudd, almoner at St George's Hospital, organized the almoners into their own committee. In 1907 Mudd's committee, unwilling to believe that the predominately male COS Administrative Council, with no experience of the work, could select the right candidates, split from the COS and formed the Hospital Almoners Council. ${ }^{126}$ The Council, which became the Institute of Hospital Almoners in 1922, now became responsible for selection and training, but it could not keep pace. By the 1950 s there were only seventy almoners in Britain, most of whom worked with the

120 COS annual report, 1897 , pp. 5-6.

121 Select Committee on Metropolitan Hospitals, 3rd report, PP, 1892, xiii; Prochaska, op. cit., note 8 above, p. 74.

122 Bell, op. cit., note 23 above, pp. 25-32.
123 Rooff, op. cit., note 13 above, p. 105.

124 Bell, op. cit., note 23 above, p. 36.

125 Prochaska, op. cit., note 8 above, p. 55.

$126 \mathrm{H}$ Bosanquet, Social work in London, 1869-1912, London, John Murray, 1914, pp. 220-1. 


\section{The Debate over Outpatient Admissions to London Hospitals}

personal and practical problems of tuberculosis. Until the creation of the National Health Service in 1948, almoners remained preoccupied with financial abuse and were mainly responsible for assessing patients' ability to pay. ${ }^{127}$ In 1939 the Ministry of Health officially saw this as their role within the wartime Emergency Medical Service. This had been only part of the COS's original aim. It had hoped that almoners would become more than outpatient gatekeepers and would help develop co-operation between health care sectors by finding the right services to suit the patient's needs and income. ${ }^{128}$ The situation changed after 1948. Hospital almoners were now seen as "one of the essential elements of a complete hospital", becoming in effect medical social workers. ${ }^{129}$ They moved closer to the COS's original conception of their role by providing information on relief agencies and so became more actively involved in medical social work, arranging practical care and help for patients.

For all the support given to the inquiry system and the general absence of criticism, it did present a dilemma. Limitation through investigation was potentially detrimental to hospital practice and a hindrance to rapid treatment. ${ }^{130}$ Governors adopted the scheme to placate popular opinion, but were reluctant to enforce investigation, as a dramatic reduction in admissions created an unfavourable impression with the benevolent public. The medical staff also sought to subordinate inquiry to protect clinical material and their authority in the outpatient departments. With vested interests against a system of full investigation, inquiry was modified to match concerns other than the issue of outpatient abuse.

\section{The Aftermath}

The debate over outpatient abuse continued to haunt the medical profession and the voluntary hospitals into the twentieth century. The passing of the Liberal government's 1911 National Insurance Act in the face of opposition from doctors and the voluntary hospitals changed the situation. ${ }^{131}$ The Act did not directly concern the London hospitals, but many in the voluntary hospital sector feared it would limit subscriptions and add to their burdens. Henry Burdett, editor of the Hospital and the "Pope" of charity, even warned that they would be swamped by the new class of insured patients. The King's Fund was more cautious, predicting that the Act would have no impact on inpatients and would lead to a different class of outpatients. Its assessment proved the more accurate. ${ }^{132}$ In 1913 inpatient admissions rose marginally and outpatient numbers fell by 200,000. The BMA was pleased with the outcome as the Act appeared to create a new consultative role for outpatient departments that would match all its members' interests. ${ }^{133}$ Trivial cases were now referred back to panel doctors, who, under the capitation scheme, were encouraged to use outpatient departments for emergency cases, and consultation under an insurance system that seemed to reflect a compulsory self-help ethos. This, according to Abel-Smith,

\footnotetext{
${ }^{127}$ E Younghusband, Social work in Britain, 1950-1975, London, George Allen \& Unwin, 1978, pp. 145-8.

128 Bosanquet, op. cit., note 126 above, p. 221.

129 Younghusband, op. cit., note 127 above, pp. 145-8.

${ }^{130}$ UCH Archive, abstract of governors' minutes, UNOF/2/3(i).
}

\footnotetext{
131 For the passing of the National Insurance Act see B B Gilbert, Evolution of national insurance in Great Britain, London, Joseph, 1966, and D Fraser, Evolution of the British welfare state, London, Macmillan, 1984.

132 Prochaska, op. cit., note 8 above, p. 75.

133 Abel-Smith, op. cit., note 4 above, pp. 244-6.
} 


\section{Keir Waddington}

helped redefine the term "outpatient abuse" and stimulated interest in contribution and payment schemes. ${ }^{134}$ Co-operation was encouraged between hospitals and panel doctors, reducing animosity. Concern now increasingly focused on hospitals' financial problems and the role of the state in providing health care. In reducing admissions and making outpatient departments serve a more consultative role, the Act achieved something hospital doctors and general practitioners had not been able to do.

In the late-nineteenth century, hospital reformers, according to a correspondent in the Lancet, became so preoccupied with the problem that they stopped seeing the benefits that hospitals offered to society. ${ }^{135}$ Burdett echoed this view, noting that the London hospitals needed "less criticism and more cash". ${ }^{136}$ The impact of the outpatient debate on hospital finance is impossible to assess, but it did generate a more critical approach to hospital management. The debate itself, however, remained unresolved.

No solution could be found because opinion was divided and vested interests were too strong to ensure a concerted move against an occurrence that could not be proved. Contemporaries believed that abuse was widespread, but historically its existence must be doubted. Nevertheless, it was this belief that motivated debate, and many saw no need for statistical evidence. The COS could see the problem in very simple and dogmatic terms, but a fundamental barrier to reform existed. Concern over abuse had been generated because it was convenient to link the growth in admissions to an abuse of charity at a time when doctors working in the capital's hospitals were trying to modify them to match their criteria. However, outpatient departments were too useful for doctors and hospital philanthropists to contemplate any radical transformation. Doctors were reluctant to cede any of their authority or seriously restrict the amount of clinical material available. Governors did not want to alienate support and attempted to instigate reform in the face of public criticism, but there was a limit to what they were willing to do because "so long as the public, in response to their piteous appeals for help, continues to supply them with funds ... so long will they continue knowingly to perpetuate evils which have now been complained of for quite a generation. ${ }^{137} \mathrm{Mr}$ Thies, secretary at the Royal Free Hospital, expressed a widespread concern among governors that refusing treatment might result in criminal proceedings and "if they drove the patients out of their hospitals they could go to other hospitals, and probably their own out-patient department would become unpopular". ${ }^{138}$ Hordes of outpatients were good for appeal purposes especially given the poor nature of most hospitals' finances, so implementation was often imperfect, removing much of the benefit any plan would have had. Reformers, philanthropists and doctors could not agree on a uniform system and no concerted effort was made to combat the perceived abuse. Out of the conflicting proposals the inquiry system emerged as the least objectionable course of action. It was a solution that left power in the hands of the doctors and governors and did not challenge the voluntary system. Implementation even of this scheme was imperfect, but at the same time, where professional interests had forced the issue, they prevented a satisfactory solution.

\footnotetext{
${ }^{134}$ Abel-Smith, op. cit., note 4 above, p. 246; $\mathrm{S}$ Cherry, 'Beyond national health insurance. The voluntary hospitals and hospital contributory schemes: a regional study'. Soc. Hist. Med., 1992, 5: pp. 455-82.

${ }^{135}$ L S Beale, 'Hospitals, the profession and the
}

public', Lancet, 1898, i: 122-3, p. 123.

${ }^{136} \mathrm{H}$ C Burdett, 'The medical staffs of hospitals and hospital abuse', Lancet, 1897, i: 771-2, p. 771.

${ }^{137}$ Hardy, op. cit., note 66 above, p. 373.

138 'Hospital reform', Br. med. J., 1897, ii: $1272-7$, p. 1276. 